\title{
Gluteal teratoma: An atypical presentation in a 2-year-old girl
}

\author{
A L Delgado, MD, FCS (COSECSA); M Mvuyisi, MB ChB; A Dhaffala, MB ChB, MMed, FCS (SA) \\ Department of Surgery, Nelson Mandela Academic Hospital and Walter Sisulu University, Mthatha, South Africa
}

Corresponding author: A Delgado (delgadoarturo15@yahoo.com)

\begin{abstract}
Most gluteal teratomas reported in the literature are lateralised sacrococcygeal teratomas. These tumours derive from more than one embryonic germ cell layer, and are usually diagnosed in infancy. We report a case of a large unilateral teratoma protruding through the left gluteus skin of a 2-year-old girl, anterior to the sacrum and coccyx. A complete excision of the tumour was achieved.

S Afr J Child Health 2019;13(3):141-142. https://doi.org/:10.7196/SAJCH.2019.v13.i3.1576
\end{abstract}

The most commonly reported gluteal teratomas in the literature are lateralised sacrococcygeal teratomas. ${ }^{[1]}$ These tumours derive from more than one embryonic germ cell layer, and are usually diagnosed in infancy. ${ }^{[2]}$ The estimated incidence of presacral teratomas in children ranges from 1 in 30000 to 1 in 43000 live births. ${ }^{[2]}$ Eighty-five percent of sacrococcygeal teratomas manifest during infancy, with an externally visible swelling. Because of the associated risk of malignancy, which increases with age, the majority of tumours undergo surgical intervention. ${ }^{[3]}$

\section{Case report}

This report describes the successful surgical excision of a large teratoma in a 2-year-old girl who had had surgery for a myelomeningocele 1 year before the current presentation. The mass had been protruding through the left gluteus skin for 3 months prior to her current admission. According to the child's mother, the teratoma had first presented as a painful swelling on the left side of the buttock, which eventually burst just prior to referral to our hospital. On physical examination, a reddish mass of $11 \times 7 \times 6 \mathrm{~cm}$, which resembled a loop of bowel, was found protruding through the skin of the left gluteal region. The girl complained of pain, and refused to play or walk.

Blood tests, including full blood count, urea and electrolytes, coagulation profile, alpha fetoprotein and liver function tests were normal.

Magnetic resonance imaging was performed, and showed a large complex pelvic mass of $11.3 \times 7.8 \times 6.8 \mathrm{~cm}$, with its cranial aspect located in the presacral/precoccigeal space, extending inferiorly and herniating outwards adjacent to the rectum off the midline to the left. The mass had cystic, fatty, solid and calcific components. There was no extension into the spinal canal.

A biopsy of the mass was performed, which was reported as a lipoma, and the girl was taken to theatre for resection of the mass, during which its lipomatous appearance was noted. The mass was in contact with the left side of the rectum and partially attached to the coccyx, but it was possible to perform a complete resection (Fig. 1).

Sections showed a mass comprising organoid, mature elements from the three germ layers. These elements included stomach, small intestine, colon, stratified squamous epithelium, mature neural elements, neuroendocrine tissue, blood vessels and connective tissue.

The coccyx was identified. There was no evidence of immature neuroepithelial elements, somatic or haematolymphoid

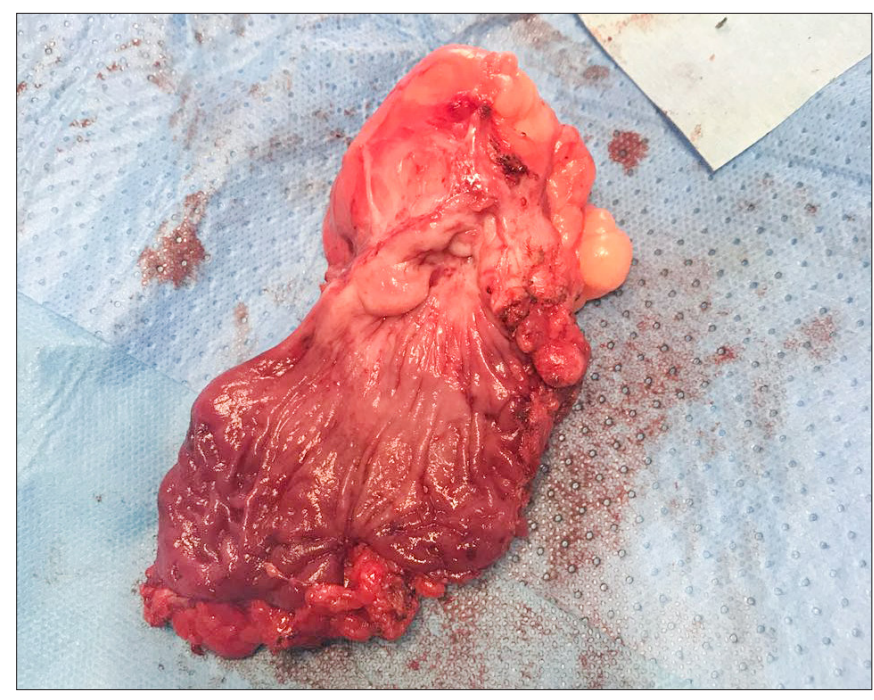

Fig. 1. Gluteal teratoma after resection.

malignancies present. It was concluded to be a mature cystic teratoma.

Postoperatively, the child recovered well, and was able to walk and play 48 hours after the operation. She was discharged a week later.

\section{Discussion}

Teratomas are known to have high malignant potential. Their risk of developing into malignant tumours has been estimated to be $30 \%$ at 7 days, $5 \%$ at 1 month and $70 \%$ at 2 years of age; therefore, early surgical excision is advocated. ${ }^{[2]}$ Additional coccygectomy forms an integral part of the surgery. ${ }^{[2]}$ Complete surgical excision (with coccygectomy) is adequate in benign tumours; however, chemotherapy and radiotherapy are indicated in malignant cases, and in cases of recurrence after previous excision. ${ }^{[4]}$ About $70-80 \%$ of the teratomas reported in the literature have occurred in girls. ${ }^{[3,5]}$ Schropp et al. ${ }^{[6]}$ reported a female:male ratio of 4.2:1 in their experience of sacrococcygeal teratomas over four decades.

Gluteal teratomas are uncommon. Lange ${ }^{[7]}$ described a benign cystic teratoma in the gluteal region. Perez Carro et al ${ }^{[8]}$ used magnetic resonance imaging to differentiate a gluteal teratoma from the more common tumours in this site that arise from fat or fibrous tissue. Sood et al. ${ }^{[9]}$ reported an 11-year-old girl who 
presented with a fetiform gluteal mass attached to the sacrum by a fibrous band, while Gajbhiye et al. ${ }^{[10]}$ reported a 4-month-old girl with an anorectal malformation and a gluteal mass, which was found to be a sacrococcygeal teratoma on excision. Jan et al ${ }^{[11]}$ described a case of a lateralised cystic sacrococcygeal teratoma mimicking a gluteal abscess.

\section{Conclusion}

The atypical presentation of this teratoma situated presacrally in the gluteal region, and protruding through the skin, motivated us to highlight this.

Acknowledgements. The authors thank Prof. Ernesto Blanco for his assistance in the review of this paper.

Author contributions. ALD conceived and wrote the whole article; MM assisted in the preparation of the article; $\mathrm{AD}$ reviewed the article.

Funding. None.

Conflicts of interest. None.

1. Dutta HK, Borah P, Baruah M. Gluteal teratoma: A rare site of extragonadal teratoma. J Indian Assoc Pediatr Surg 2016;21(4):178-180. https://doi. org/10.4103/0971-9261.158097

2. Bull J Jr, Yeh KA, McDonnell D, Caudell P, Davis J. Mature presacral teratoma in an adult male: A case report. Am Surg 1999;65:586-591.
3. Bhosale M, Singh D, Gupta A. Rare presentation of sacrococcygeal teratoma in a prepubertal girl. CHRISMED J Health Res 2015;2(4):364-366. https://doi. org/10.4103/2348-3334.165734

4. Keslar PJ, Buck JL, Suarez ES. Germ cell tumours of the sacrococcygeal region: Radiologic-pathologic correlation. Radiographics 1994;14(3):607-620. https:// doi.org/10.1148/radiographics.14.3.8066275

5. Tapper D, Sawin R. Teratomas and other germ cell tumours. In: O’Neill JA, Rowe MI, Grosfeld JL, Fonkalsrud EW, Coran AG, eds. Pediatric Surgery. 5th edition. St Louis: Mosby, 1998:447-460.

6. Schropp KP, Lobe TE, Rao B, et al. Sacrococcygeal teratoma: The experience of four decades. J Pediatr Surg 1992;27(8):1075-1078. https://doi. org/10.1016/0022-3468(92)90563-m

7. Lange TA. Benign cystic teratoma. In: Steinberg ME, ed. The Hip and its Disorders. Philadelphia: WB Saunders, 1991:572-575.

8. Perez Carro L, Manuel Palazuelos C, Echevarria Llata JI, Sumillera Garcia M, Sune Gracia C. Magnetic resonance imaging (MRI) of a benign cystic teratoma in the gluteus region. Int Orthop 1993;17(4):245-247. https://doi.org/10.1007/ bf00194189

9. Sood N, Kamboj M, Chaabra M. Sacrococcygeal fetiform teratoma Altman type 1: A rare case report in an 11-year-old girl. Indian J Surg 2013;75(Suppl 1):S359-S361. https://doi.org/10.1007/s12262-012-0703-5

10. Gajbhiye V, Chatterjee S, Nath S, Ghosh D, Konar H, Das SK. An unusual unilateral gluteal mass in a case of anorectal malformation. J Surg Arts 2014;7:36-38. https://doi.org/10.14717/jsurgarts/2014.116

11. Jan IA, Hazratullah, Ishaque N, et al. Unusual presentation of sacrococcygeal teratomas in paediatric patients. Saudi J Health Sci 2012;1(1):30-34. https://doi. org/10.4103/2278-0521.94981

Accepted 7 January 2019 